\title{
Indigenous Aeta Magbukún Self-Identity, Sociopolitical Structures, and Self-Determination at the Local Level in the Philippines
}

\author{
Vincent S. Balilla, ${ }^{1}$ Julia Anwar McHenry, ${ }^{2}$ Mark P. McHenry, ${ }^{3}$ \\ Riva Marris Parkinson, ${ }^{1}$ and Danilo T. Banal ${ }^{4}$ \\ ${ }^{1}$ Peninsula Ecosystems and Health Foundation Inc., Philippines \\ ${ }^{2}$ Faculty of Health Sciences, Curtin University, Australia \\ ${ }^{3}$ School of Engineering and Information Technology, Murdoch University, Western, Australia \\ ${ }^{4}$ Institute for Foundational Learning Inc., Philippines
}

Correspondence should be addressed to Vincent S. Balilla; vsbalilla@yahoo.com.ph

Received 7 December 2012; Accepted 1 April 2013

Academic Editor: Santos Alonso

Copyright (C) 2013 Vincent S. Balilla et al. This is an open access article distributed under the Creative Commons Attribution License, which permits unrestricted use, distribution, and reproduction in any medium, provided the original work is properly cited.

\begin{abstract}
The Indigenous Aeta Magbukún maintain a primarily nomadic hunter-gatherer lifestyle in their forested ancestral lands. Through the continued encroachment of non-Indigenous populations, the Aeta Magbukún persist at a critical level. Finding it increasingly difficult to sustain their traditional livelihoods, they must engage in informal commerce to procure sufficient food throughout the year. This work explores the basis of self-identity, traditional kinship ties, evolution of sociopolitical organisation, and the developing political options that sustain the small and vulnerable Indigenous population. Despite recent tentative sociopolitical developments, securing cultural protection requires greater effort in developing political communication and representation at a local and national level. In doing so, the Aeta Magbukún can meet their basic needs, secure traditional cultural knowledge, and are able to influence their own development during a time of relatively rapid acculturation within the mainstream Philippine societal complex.
\end{abstract}

\section{Introduction}

Indigenous people are commonly defined as the descendants of the inhabitants of a country or region who are present when people of different ethnic or cultural origins arrive and later become dominate through settlement or occupation of some means [1]. Bodley [2] proposes that Indigenous peoples had control of much of their own lands around the globe up until the beginning of the industrial revolution. However, this oversimplifies a very complex and controversial topic of the displacement of Indigenous peoples unrelated to European colonisations [3-5]. Indigenous identity, when defined by the original inhabitants, can be contested using a range of methods, and it is possible to discern several waves of migration and occupation, even in regions with complex migratory histories such as south and eastern Asia [3-5]. While the UN system body has not adopted an official definition of "Indigenous," as a result of the diversity of Indigenous peoples, a Working Group on Indigenous Populations established in 1982 developed a working definition in 1994. The modern interpretation of the term Indigenous includes self-identification, both at an individual and a community level, historical continuity with "preinvasion" and "precolonial" societies and is linked to traditional territories and surrounding natural resources $[2,6]$. Rather than attempting to define Indigenous peoples, the UN prefers to identify who Indigenous peoples are, and, therefore, selfidentification is a fundamental criterion for concerns centred on human rights considerations [7]. Indigenous minority ideologies, cultures, and priorities often contrast that of modern mainstream society, adding further complexity to already challenging human rights and equity concerns [2]. When Indigenous peoples become a minority population in a modern society, they often strongly desire to maintain 
and impart their distinct social and economic structures, politics, language, culture, traditional lands, and beliefs to future generations $[2,6]$. At its most extreme, Indigenous people seek political autonomy and self-sufficiency but ultimately strive for effective self-determination as a basic human right to influence decisions impacting on their quality of life [3]. At its most basic, the focus is directed towards equitable access to adequate provisions, education, health care, and basic infrastructure [2].

Indigenous identities are contested in the Philippines as a result of successive ways of migration of many different peoples throughout the Asian region, long before the arrival and colonisation by Europeans [8]. The Philippines contains a great diversity of peoples with over 169 living ethnolinguistic groups, about 140 of which are acknowledged as Indigenous [9]. Of the 78 provinces that make up the Philippines, Indigenous peoples are present in more than 50 and, depending on the definition of Indigenous populations used, represent from 10 to 20 percent of the total Philippine population $[9,10]$. Such a high density of cultural, language, and ethnicity differentiation among Indigenous peoples in the Philippines arose as a result of geographical segregation, and many of these populations retreated into isolated regions during successive events related to immigrations, displacement, discrimination, and more recently economic development [2].

One of the most well-known Indigenous groups in the Philippines is the Aeta, found in central (Aeta, Ita), eastern (Dumagat), and southeastern Luzon (Agta), as well as several islands in the Visayas (Ati). In the Bataan Peninsula of central Luzon, a single Indigenous group, known as the Aeta Magbukún can be found living near the fringe of the Manila Bay/South China Sea and the forest cover of Mount Mariveles in the Philippines. The Aeta Magbukún are one of the least studied Indigenous groups in the Philippines, and despite the encroaching population of non-Indigenous peoples, they have maintained a primarily traditional huntergatherer existence [11]. Mariveles is a municipality with a population of 102, 844 (in 2007), located at the southern tip of the Bataan Peninsula, about $173 \mathrm{~km}$ from the capital Manila with a cove bounded on its eastern, western, and southern sides by the Manila Bay and South China Sea (Figure 1). Mariveles is composed of eighteen barangays (settlements) lying along the coastal and flat lands, with larger and predominantly undeveloped mountainous areas where the Aeta Magbukún live. The Aeta Magbukún's bayanbayanan (village/hamlet), recently constructed by an NGO, is a separate site within barangay Biaan, the smallest barangay in terms of population, yet one of the largest in terms of land area. Only two years ago, an overgrown and unmaintained earthen road led to the Aeta Magbukún's bayan-bayanan from the local town centre. Recently the road has been upgraded and renamed to become the Mariveles-Bagac Highway. This and other related developments have resulted in a cultural upheaval for Aeta Magbukún and a growing fear of losing their unique language and culture.

Consideration over Indigenous peoples, rights entered the international arena in the 1970s in a self-determination movement, supported by regional, national, and international organisations representing Indigenous interests and either driven directly or largely supported by the Indigenous peoples themselves [2]. Modern ethnographical, anthropological, and more recent molecular genetic approaches have since enabled an unprecedentedly detailed understanding of Indigenous peoples. In the Philippines, lack of basic social services and high poverty have forced many Indigenous people to move off their traditional lands, and the human rights violations from encroaching economic activity and continued development of regional areas are of ongoing concern [9]. Thus, documenting the remarkably unique and ancient traditional livelihood of the Aeta Magbukún is a fundamental driver for this research. This work uses an ethnographic approach to facilitate broader intercultural awareness, human rights advancement, and an understanding of the basic right of Indigenous peoples to live in their traditional lands, even when their unique Indigenous status goes unnoticed or is highly contested $[2,4,12]$.

\section{Basic Demography and Population Structure}

At the end of 2008 the total population of the Aeta Magbukún's bayan-bayanan was 107 , with a total of 21 nuclear families. (The authors would like to note that most of the tribe remains nomadic and travels extensively within the Mariveles forests. The bayan-bayanan with permanent buildings is primarily a development derived from the establishment of an Aeta school at the site provided by another NGO. As such, many children stay in the bayan-bayanan due to practicalities of proximity, as the Aeta Magbukún place a high value on their children's education.) Population sex ratios included 63 (59 percent) males and 44 (41 percent) females, with 72 (67 percent) of the total population aged between zero and thirty (Figure 2). The average size of an Aeta Magbukún nuclear family is five family members, including the mother and father. In the period from 1990 to 2008, there was an average of three live births per annum. Only ten (nine percent) of the community are non-Aetas, and all of them are spouses of Aetas. Thus, ten out of twenty-one (47 percent) married couples in the bayan-bayanan are of mixed marriage, which is a recent phenomenon, as genetic studies indicate a distinct homogenous genetic history, quite apart from the rest of the Philippine population and Asia-Pacific generally [13-18].

\section{Aeta Magbukún Group Psychology: The "Aeta" Self-Representation}

Common names that identify Aetas from non-Aetas in the Philippines include kulot (curly haired Aetas) as opposed to unat (straight-haired non-Aetas) and Aeta as opposed to Tagalog. (Tagalog is the most common ethnolinguistic group in Luzon, Philippines.) The Aeta Magbukún often refer to non-Aetas in the third person as tao, which, in Tagalog, literally means "a person." When asked in the Aeta Magbukún language, "Kung tao ako, eh ano ka?" (translated into English as "If I am a person, then what are you?"), an Aeta Magbukún would simply answer "Aeta." The use of these terms does not suggest that the Aeta Magbukún 


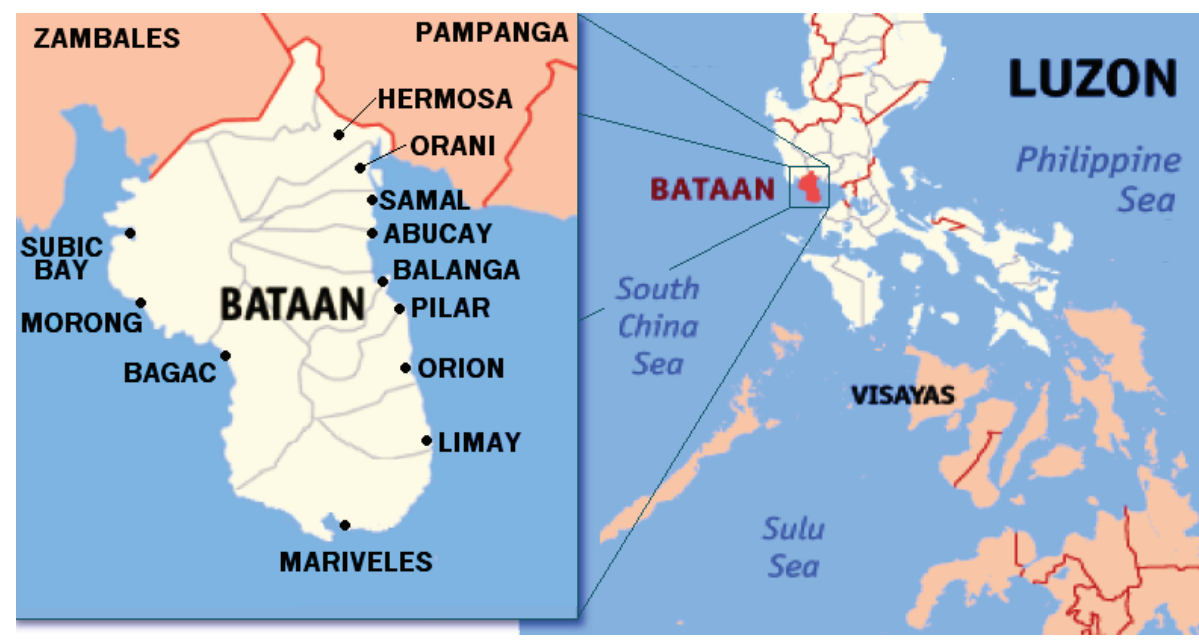

Figure 1: The Bataan Peninsula, Philippines.

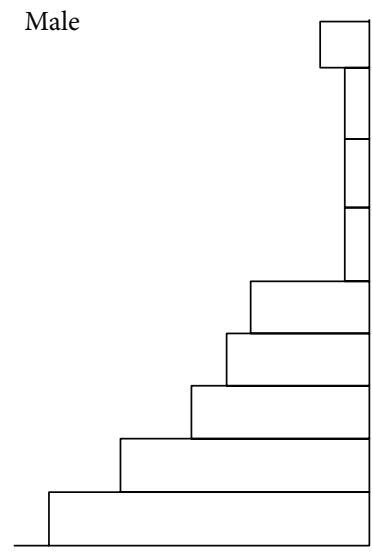

$\begin{array}{llllllllll}20 & 18 & 16 & 14 & 12 & 10 & 8 & 6 & 4 & 2\end{array}$

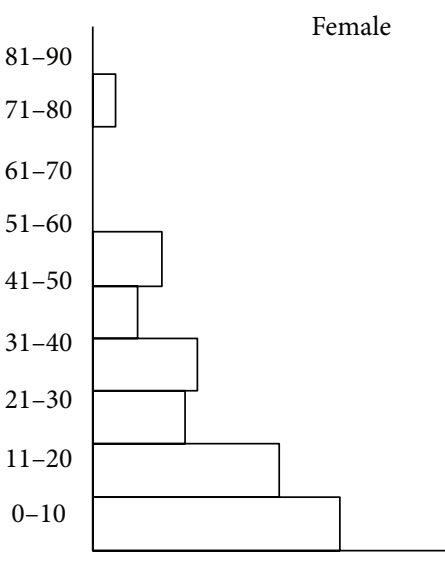

$\begin{array}{llllll}2 & 4 & 6 & 8 & 101214161820\end{array}$
FIgURE 2: Aeta Magbukún population pyramid.

have a different existential philosophy; it is simply how they recognise themselves as distinct from non-Aetas. Conversely, within the several groups of Indigenous peoples of the Philippines and other closely related Aeta groups, such sharp distinctions are common.

The Chieftain of the Aeta Magbukún explained the term Magbukún originated from the word bukud/magbukud, which literally means "to separate from" in the Aeta Magbukún language. Aeta Magbukún, and women in particular, are known for their reclusive shyness in social situations, particularly outside of their own bayan-bayanan. Despite this shyness, in some situations Aetas are known to passionately defend their distinctiveness as Aeta Magbukún as opposed to other Aeta groups and non-Aeta alike. For example, a shy Aeta Magbukún mother of two was mistaken for a "Pinatubo Aeta" ("Pinatubo Aeta" is the common name given by Aeta Magbukún to describe displaced Aetas from the Mount Pinatubo locale of Zambales, Tarlac, or Pampanga to the north of Bataan who are stereotypically viewed as beggars. This is relatively common in some places as a result of the devastating 1990 Mount Pinatubo volcanic eruption, evacuation, resettlement, and associated social upheaval) by a vendor at the local marketplace, who had subsequently driven her away. Despite her shyness, the mother was so irritated that she confronted the vendor saying "'Di ako namamalimos! Hindi ako Pinatubo! Heto ang pera ko!" ("I am not a beggar! I am not from Pinatubo! Here's my money!"). The Chieftain's wife described how she felt ashamed when she sees "Pinatubo Aetas" begging around Mariveles and the marketplace. As a result she also tends to be very reclusive outside of her own bayan-bayanan, as she fears she will be mistaken as a "Pinatubo Aeta" and treated as such. On one occasion, while selling honey (an important Aeta Magbukún traditional food gathered seasonally from the forest) a man approached the Chieftain's wife and gave her a five Peso coin. She immediately answered "Di ho ako namamalimos...nagbabanat ho ako ng buto..." ("Please, I am not a beggar...I work to the bone..."). She then gave the five Peso coin back to the man. These examples show both the pride and sensitivity of the Aeta Magbukún's sense of self-identity. The specific annoyance towards being recognised as "Pinatubo Aetas" stems from their belief that it is particularly shameful for an ablebodied Aeta to resort to begging. This is compounded by the relatively short travelling distance between main centres in the Bataan and Zambales regions and shared physical features between Aeta groups. The differentiated Aeta identity enables the Aeta Magbukún to present themselves as a distinguished Aeta group that has lived relatively independently since preEuropean colonisation.

\section{Social Organisation and Institutions}

The social organisation of the Aeta Magbukún revolves around the nuclear family as the basic social unit of the community. However, this nuclear family is interdependent on other nuclear families bound together by kinship. Kinship defines social norms, obligations, and relationships based on social rather than biological relationships among family groups or clans [19]. In the Philippines generally, kinship 
is bilateral, meaning that individuals have social obligations and responsibilities to both their mother's and father's relations, and is generationally structured by age and order of descent, such as among siblings [20]. While the role of kinship and the extent of social differentiation and integration differ among societies [19], kinship can define, order, and express relationships, rights, and obligations within a community. In this sense, it not only creates both harmony and structure within group relationships, but can also be responsible for causing conflict when expectations surrounding kinship are not imposed or observed [20].

\section{Aeta Magbukún Kinship and Sociopolitics}

The Aeta Magbukún community in the Biaan barangay is almost entirely made up of a single family grouping, the Maingat clan. Of the twenty-one nuclear families, seventeen of them belong directly to the Maingat clan. The remaining four nuclear families do not belong to a single family grouping, although they are still closely associated with the Maingat clan. From a single nuclear family composed of nine siblings, the Maingat clan grew to be the major family group in the Aeta Magbukún community of Mariveles. The seventeen nuclear families in the Maingat clan are composed of 90 individuals. Thus, of the total population of 107, only seventeen individuals do not directly belong to the Maingat clan. The close solidarity within this family group can be seen clearly during food hunting, gathering activities, and food sharing. As with other Philippine groups generally, the Aeta Magbukún observe kinship relationships based on family relationships, order of decent, and age. Additionally, the Kagun (healers) and the Chieftain and his family hold special status in addition to these kinship relationships. Whilst the basic communal relations within this tribe revolve around the dynamic relations within and among members of the Maingat clan, the traditional decision-making body within the tribe is a council of elders. This Indigenous political institution is primarily composed of elderly Aetas revered for their years of accumulated knowledge, wisdom, and ability. The council of elders serves as spiritual and cultural advisers and, along with a tribal council, handles intratribal conflict resolution [21]. If an amicable settlement cannot be made, or when there are conflicts between non-Magbukún and Magbukún, the tribal council will refer the issue to the Municipal Council [21].

The dominant political structure among the Aeta Magbukún of Mariveles, at present, is a democratised "Tribal Council," composed of elected Aeta officials. The Tribal Council is made up of the Chieftain, two tribal kagawad (councillors), a secretary, a treasurer, and an auditor. The Tribal Council's primary concern is the representation of Aeta affairs to the Municipal Council, including decision-making, conflict resolution, and the formulation and implementation of specific tribal decrees [1]. As family groups provide the basic structure of the Aeta Magbukún's social organisation and sociopolitical structure, the current Tribal Council officers, including the Chieftain, are all from the Maingat clan. The Magbukún Tribal Council, headed by the chief, govern the community and are generally selected on the strength of their political influence [21]. Nevertheless, the Council are viewed as the representatives of the State within the village [1]. The Tribal Council aims to progress the Aeta Magbukún's right to self-governance, while also representing and ensuring the tribe's participation in local, regional, and national affairs (i.e., barangay, municipal, provincial, regional, and national levels).

\section{Local Power Structures and Collective Action}

In November 2008 a total ban on charcoal production was ordered by the Municipal Mayor, and a major checkpoint was established to prevent distribution. (Charcoal production in the forest is a traditional Aeta Magbukún practice and in recent times has become an important source of income during the wet season when the tribe is often critically in short supply of food. In recent years the tribe has produced charcoal to purchase additional food, mostly rice) The incident was met with much anxiety among the Aeta community and prompted an Aeta elder, estimated at 65 years old, to call for Aeta unity on the basis of strong feelings of worry for the plight of Aeta and the discrimination they experience. In the words of another elder: "Paano na kami? Paano na tayo kung ipagbabawal ang uling? Gugutumin ang pamilya namin! Napakamahal ng bigas ngayon. . Paano ko mababayaran ang mga utang ko sa grocery? Ano ang ating gagawin?" ("What will happen to us? What will happen to us if charcoal is banned? Our family will starve! Rice is so expensive nowadays. .. How will I pay my debts in the grocery? What are we going to do?"). Another elder suggested "Kausapin natin si Mayor!" ("Let's talk to the Mayor!"). Another community member commented "Dapat lahat tayo pumunta doon, isama natin mga anak natin, para makita nilang nagugutom..." ("We should all go there (to the Mayor's office), we should bring our children so they can see that they are starving..."). The Aeta decided that some immediate action must be taken, and despite a few contentions, a unanimous decision was made with both the Chieftain's and the Tribal Council's approval. The entire bayan-bayanan marched to the town of Mariveles to talk to the Mayor. The whole Aeta community, seemingly on an exodus, understandably surprised the non-Aeta people in town. "Oh, saan ang piesta?" ("Oh, where's the fiesta?"), a man jokingly asked the passing Aetas, as seeing the Aeta en masse in the town is a rare event. If it had not been for an advanced courtesy call from the Aeta community's elementary school teacher, the Municipal Council would have been very surprised at the arrival of the entire Aeta tribe. Led by the Chieftain, the Aetas were shown immediately inside the Munisipyo (Municipal Hall).

An emergency meeting was called, and in the absence of the town Mayor, the Aetas were greeted by the Mariveles Municipal Councillor who heads the Cultural Minorities Committee. Also present were several other Mariveles Municipal Councillors, the Bantay Gubat (Public Safety Officers), and the District Supervisor of the Department of Education in Mariveles. The Aeta community expressed their complaints and sentiments, and while the Municipal 
Council explained that charcoal production was illegal, they were willing to provide an alternative livelihood for them. The Aeta learned that an annual 100,000 Peso allotment was available to them and were taken aback when they were then asked what livelihood they wanted. The Aetas hastily, yet unanimously, stated they would like pananim (plants to cultivate), and to facilitate cultivation, they also requested for fertiliser, plows, and two carabaos (a domesticated water buffalo native to southeast Asia, Bubalus bubalis) to pull them. This was despite the hunter-gatherer tribe having very little knowledge of plant cultivation or carabao husbandry. (When asked subsequently of why they asked for plants and agricultural capital, the Aetas stated that they did not know anything else they could ask for. Predictably, the plant cultivation was not successful as the Aetas had little knowledge of planting common (to non-Aetas) vegetables, ploughing, fertilising, tending, or harvesting practices.) Nonetheless, at the time the whole Aeta community was exhilarated with the meeting.

The decision to initiate a dialogue between themselves and the Municipal Council proved to be politically successful at the municipal level. Only one month after the meeting, the Municipal Council provided the Aetas what they had requested. The Aetas demonstrated to themselves that they were able to collectively undertake relatively successful political action, and since that first meeting, the Aeta Magbukún tribe initiated regular monthly Tribal Council meetings. As with other Indigenous people around the world, the Aeta Magbukún were able to attract the attention of governance and authority figures by politically mobilising to voice their collective concerns. Arguably, an increased interest in the welfare and rights of Indigenous people globally over the past 40 years has done much to make these achievements possible, but nonetheless, further documentation of the Aeta Magbukún and their culture, traditions, and language will assist in distinguishing them as true Indigenous peoples of Bataan. Despite these small local victories and growing selfrealisation of their rights as Indigenous peoples, the Aeta Magbukún have a long road to travel to ensure their cultural survival through national and international recognition to meet even basic needs as protection of their ancestral lands.

\section{Conclusion}

The Aeta Magbukún way of life has remained independent from mainstream Philippine society over several thousands of years. However, due increased economic activity and encroachment of non-Aeta on traditional lands, the Aetas traditional livelihoods and way of life are threatened. To ensure their basic human rights and quality of life, the Aetas are increasingly required to participate in the formal and informal non-Aeta economy with whom they increasingly share their traditional lands [2]. The Aeta Magbukún acknowledge that they are, as with most Indigenous peoples around the world, both socially and economically marginalised. Yet they have a strong sense of self-identity and are committed to selfdetermination for the betterment of their people, culture, and unique way of life.
Drawing attention to the plight of various Indigenous peoples generally is commonly illustrated through historical discrimination and oppression [22]. Increasing awareness of the livelihood, sociopolitical structure, and general predicament of specific Indigenous peoples can contribute to improved political representation, further claims for special protection, and potentially secure future self-determination [12]. However, progress with Indigenous rights will be particularly challenging without support from national governments, non-government organisations, and the broader nonAeta community.

\section{References}

[1] J. C. Gaillard, "Traditional societies in the face of natural hazards: the 1991 Mt. Pinatubo eruption and the Aetas of the Philippines," International Journal of Mass Emergencies and Disasters, vol. 24, pp. 5-43, 2006.

[2] J. H. Bodley, Victims of Progress, AltaMira Press, Lanham, Md, USA, 2008.

[3] J. J. Corntassel and P. Hopkins, "Indigenous "sovereignty" and international law: revised strategies for pursuing 'selfdetermination,' Human Rights Quarterly, vol. 17, no. 2, pp. 343365, 1995.

[4] A. Béteille, “The idea of indigenous people," Current Anthropology, vol. 39, no. 2, pp. 187-191, 1998.

[5] H. Weaver, "Indigenous identity: what is it, and who really has it?" American Indian Quarterly, vol. 25, pp. 240-255, 2001.

[6] United Nations, The Concept of Indigenous Peoples. Background Paper Prepared by the Secretariat of the Permanent Forum on Indigenous Issues For the Workshop on Data Collection and Disaggregation For Indigenous Peoples, Department of Economic and Social Affairs, United Nations, 2004.

[7] United Nations, "Who are indigenous peoples?” United Nations Permanent Forum on Indigenous Issues: Indigenous peoples, Indigenous voices factsheet, 2006, http://www.un.org/esa/ socdev/unpfii/documents/5session_factsheetl.pdf.

[8] R. L. Barsh, "Indigenous peoples and the UN commission on human rights: a case of the immovable object and the irresistible force," Human Rights Quarterly, vol. 18, no. 4, pp. 782-813, 1996.

[9] United Nations Economic and Social Council, "59th Session, Item 15 of the provisional agenda. Report of the Special Rapporteur on the situation of human rights and fundamental freedoms of indigenous people, Mr. Rodolfo Stavenhagen, submitted in accordance with Commission on Human Rights resolution 2002/65," Addendum: Mission to the Philippines. Human rights and indigenous issues. Commission on Human Rights, 2003, http://www.ihumanrights.ph/hr-mechanism/human-rights-bodies/charter-based-bodies/special-procedures/ reportsrecommendations/report-of-the-special-rapporteur-onthe-situation-of-human-rights-and-fundamental-freedoms-ofindigenous-people-mr-rodolfo-stavenhagen/.

[10] F. Hirtz, "It takes modern means to be traditional: on recognizing indigenous cultural communities in the Philippines," Development and Change, vol. 34, no. 5, pp. 887-914, 2003.

[11] V. S. Balilla, J. Anwar McHenry, M. P. McHenry, R. M. Parkinson, and D. T. Banal, "Aeta Magbukún of Mariveles: traditional Indigenous forest resource use practices and the sustainable economic development challenge in remote Philippine regions," Journal of Sustainable Forestry, vol. 31, pp. 687-709, 2012. 
[12] M. R. Dove, "Indigenous people and environmental politics," Annual Review of Anthropology, vol. 35, pp. 191-208, 2006.

[13] T. Ishida, K. Yamamoto, and K. Omoto, "Seroepidemiological survey of HTLV-1 in the Philippines," International Journal of Epidemiology, vol. 17, no. 3, pp. 625-628, 1988.

[14] S. Horai, K. Omoto, T. Juji et al., "The HLA antigens of two negrito populations in the Philippines," Tissue Antigens, vol. 17, no. 3, pp. 343-348, 1981.

[15] H. Matsumoto, T. Miyazaki, K. Oinoto et al., "Population genetic studies of the Philippine Negritos. II Gm and $\mathrm{Km}$ allotypes of three population groups," American Journal of Human Genetics, vol. 31, no. 1, pp. 70-76, 1979.

[16] M. Kayser, Y. Choi, M. Van Oven et al., "The impact of the Austronesian expansion: evidence from mtDNA and $\mathrm{Y}$ chromosome diversity in the Admiralty Islands of melanesia," Molecular Biology and Evolution, vol. 25, no. 7, pp. 1362-1374, 2008.

[17] M. Kayser, S. Brauer, G. Weiss, W. Schiefenhövel, P. A. Underhill, and M. Stoneking, "Independent histories of human Y chromosomes from Melanesia and Australia," American Journal of Human Genetics, vol. 68, no. 1, pp. 173-190, 2001.

[18] F. Delfin, J. M. Salvador, G. C. Calacal et al., "The Ychromosome landscape of the Philippines: extensive heterogeneity and varying genetic affinities of Negrito and nonNegrito groups," European Journal of Human Genetics, vol. 19, no. 2, pp. 224-230, 2011.

[19] B. Farber, Comparative Kinship Systems: A Method of Analysis, John Wiley \& Sons, New York, NY, USA, 1968.

[20] F. Landa Jocano, "Elements of Filipino social organization," in Philippine Kinship and Society, pp. 1-26, New Day Publishers, Quezon City, Philippines, 1989.

[21] Tebtebba Foundation, Philippine Indigenous Peoples and Protected Areas: Review of Policy Implementation, Forest People's Programme series on forest peoples and protected areas. A contribution to the World Conservation Congress, October 2008. Working draft (August 2008) Forest Peoples Programme, 2008.

[22] A. Xanthaki, Indigenous Rights and United Nations Standards: Self-Determination, Culture and Land, Cambridge University Press, Cambridge, UK, 2007. 

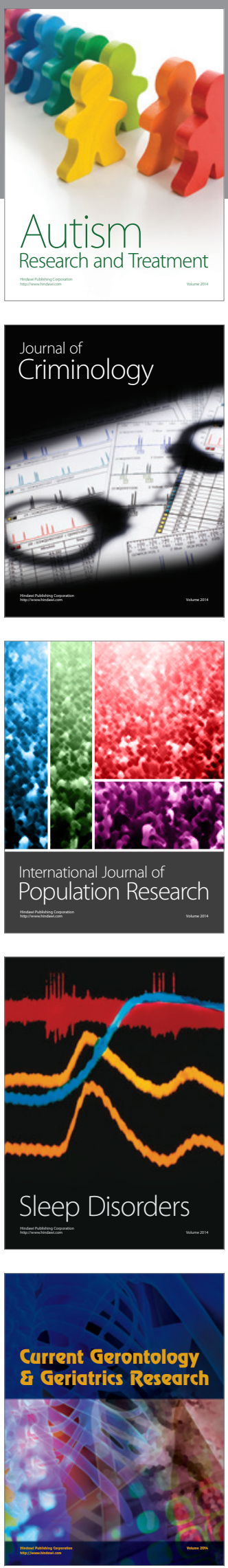
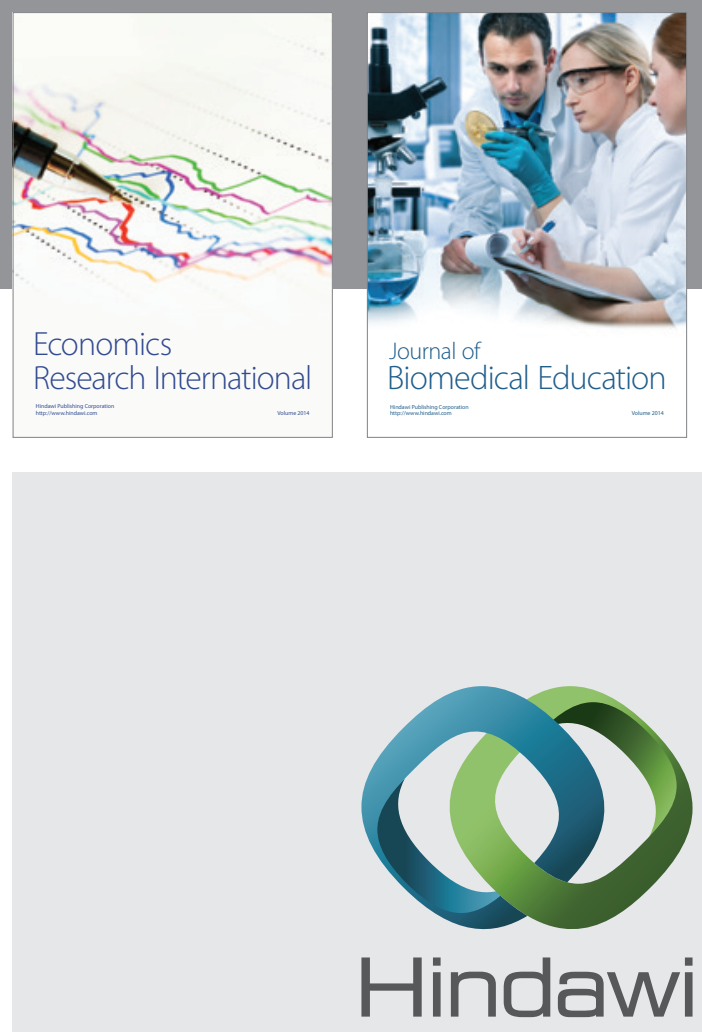

Submit your manuscripts at

http://www.hindawi.com
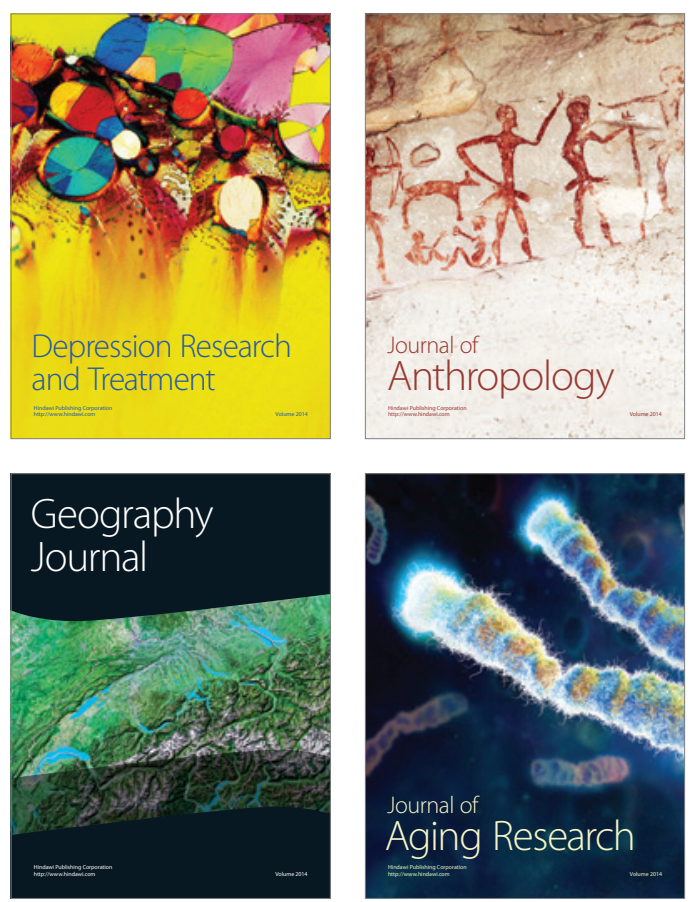
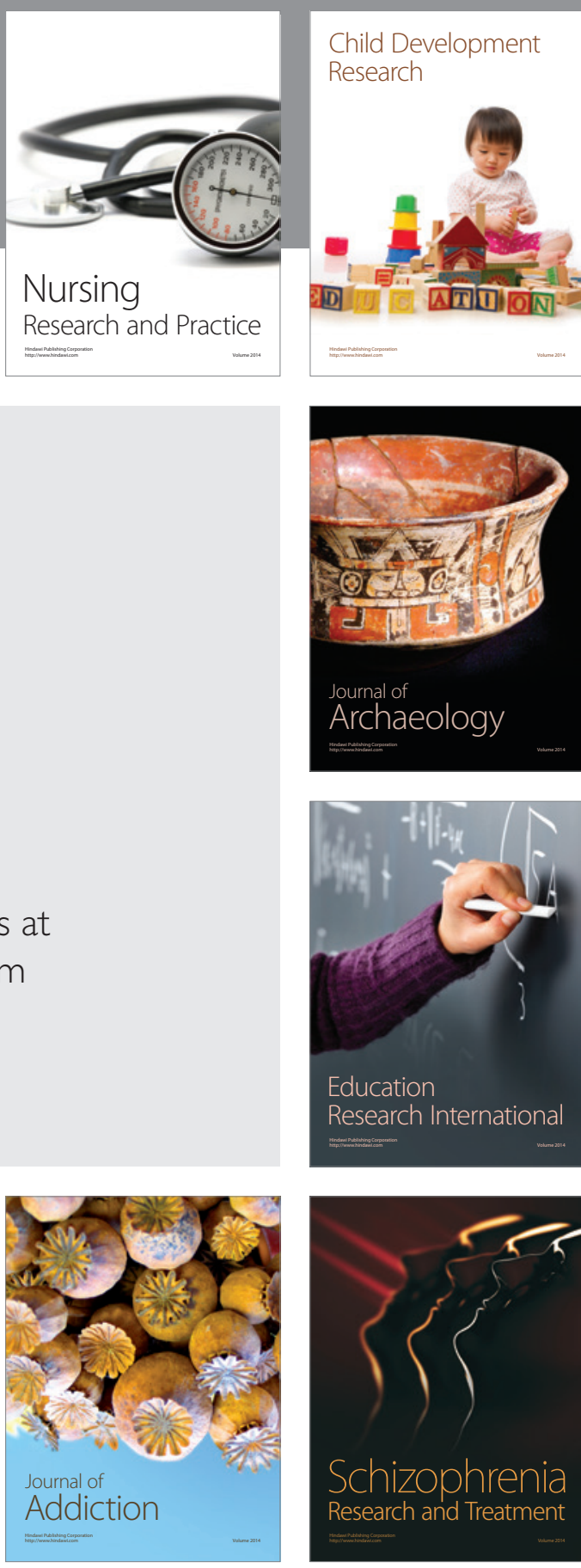

(D)
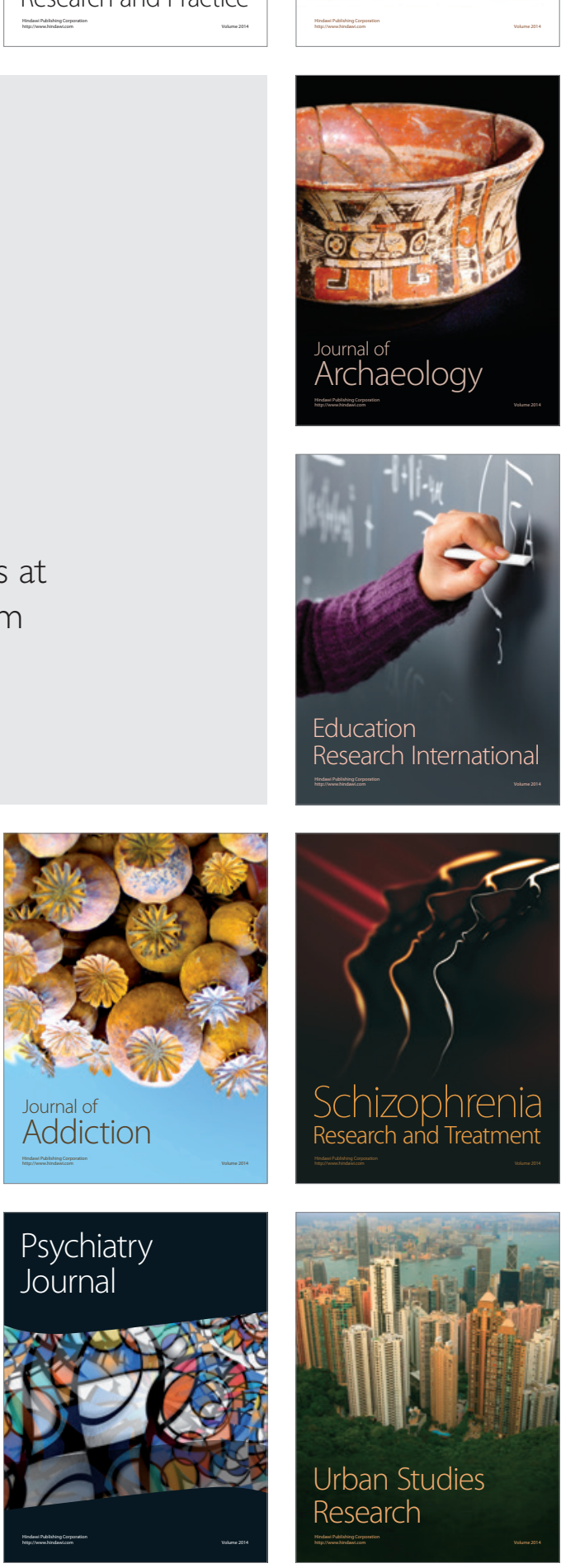